\title{
The Acute Toxicity of Copper to Nile Tilapia (Oreochromis niloticus) Fingerlings and its Effects on Gill and Liver Histology
}

\section{Akram I Alkobaby* and Rasha K Abd El-Wahed}

Faculty of Agriculture, Department of Animal Production, 'Fish Production' Unit, Cairo University, Egypt

\begin{abstract}
This study was carried out to evaluate the response of Nile tilapia, Oreochromis niloticus to acute copper toxicity. Nile tilapia fingerlings $(2.97 \mathrm{~g} / \mathrm{f} \pm 0.37)$ were acclimated and randomly distributed at a rate of 10 fish per $60-\mathrm{L}$ aquarium. In a series of static renewal-toxicity tests, fish were exposed to concentrations of $0,5,10,15,20,25$, 30,35 and $40 \mathrm{mg} \mathrm{L}^{-1}$ copper sulfate $\left(\mathrm{CuSO}_{4} \cdot 5 \mathrm{H}_{2} \mathrm{O}\right)$. Fish not exposed to any chemical served as negative controls

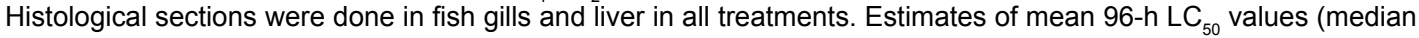
lethal concentration) value of copper sulfate was $31.2 \mathrm{mg} \mathrm{L}^{-1}\left(7.94 \mathrm{mg} \mathrm{copper} \mathrm{L}^{-1}\right)$. In all exposure groups, some of the typical gill lesions are presented. The main alternations observed after the exposure to the cupper were epithelial hyperplasia, lifting of the lamellar epithelium, edema in the filamental epithelium, Curling, clubbed tips of secondary lamella and finally a complete fusion of several secondary lamellae at the $35 \mathrm{mg} \mathrm{CuSO}$ concentration. The severity of the lesions detected increased with the increase of copper sulfate concentration. Exposure to concentrations of copper sulfate more than $10 \mathrm{mg} \mathrm{L}^{-1}$ increased the arithmetic thickness of secondary lamella epithelium in $\mathrm{O}$. niloticus which was significantly higher $(P<0.001)$ than the corresponding control. However, the liver of the Cu-treated fish showed histological alternations such as cytoplasmic rarefaction, an increase of cytoplasmic vacuolation, decreasing the number of hepatocytes nucleus in hepatic tissue and nuclear pyknosis.
\end{abstract}

Keywords: Nile tilapia; Oreochromis niloticus; Copper; $\mathrm{Cu}$; $\mathrm{CuSO}_{4}$ Toxicity; $\mathrm{LC}_{50}$; Gills; Liver

\section{Introduction}

Copper is an essential trace metal which plays an important role in several fish metabolic functions. It represents a crucial role in several enzymatic processes (e.g. enzymes involved in cellular respiration, free radical defense, neurotransmitter function, connective tissue biosynthesis and other functions), as well as, into some structural proteins [1-3]

In latest years, environmental pollution from heavy metals has been intensively examined in freshwater ecosystems due to the bioaccumulation and toxicity of these metals [4]. Regardless of its important role in cellular metabolism, copper $(\mathrm{Cu})$ is of particular interest because it is extremely toxic for aquatic animals if elevated concentrations are introduced into the water [5-8]. High copper levels can cause fast generation of reactive oxygen species [9]. It also binds histidine, cystein- and methionine-containing proteins, resulting in dysfunction [10].

The recommended $\mathrm{Cu}$ concentrations for fish therapeutic and control of algae and vascular plants in aquaria and fish ponds purposes usually range from 0.05 to $1.0 \mathrm{mg} \mathrm{L}^{-1}$ [11-13]. When copper is used in agriculture as fungicide and biofertilizer [14,15], the residual solution is eventually directed to the effluents. Therefore, copper is a pollutant found worldwide in aquatic ecosystems at concentrations ranging from 0.04 to $294 \mu \mathrm{g} \mathrm{L}^{-1}$ or, in extreme conditions, up to $20 \mathrm{mg} \mathrm{L}^{-1}$ [16].

Most of copper ions in natural waters are not free, since usually copper is associated with inorganic ions or organic substances. However, it is normal to use copper sulfate $\left(\mathrm{CuSO}_{4}\right)$ in Egypt and worldwide as an inorganic algaecide in commercial and recreational fish ponds to control the growth of phytoplankton and filamentous algae and to control many fish disease [12,17]. References [18-20] recommended a wide range of copper sulfate concentration ( 1 up to $\left.100 \mathrm{mg} \mathrm{L}^{-1}\right)$ when it is used for therapeutic purposes according to the disease, such as reducing the incidence of fish endoparasites like protozoa, trematodes, and external fungi and bacteria. However, the concentrations of $\mathrm{CuSO}_{4}$ used for phytoplankton control are seldom directly toxic to fish, but do kill large numbers of rotifers, cladocerans, and copepods [12]

Worldwide, tilapias (including all species) are the second most important group of farmed fish after carps, and the most widely grown of any farmed fish [21]. Nile tilapia (Oreochromis niloticus) is by far the most important species [22]. Egypt is the second largest producer of farmed Nile tilapia, which considered the most common fish currently being, cultured commercially [21]. However, Nile tilapia is an omnivorous fish which eats detritus, phytoplankton and zooplankton $[23,24]$ and, consequently, can accumulate copper compounds.

To measure the effects of single or complex mixture of contaminants on the organisms, toxicity tests are conducted. In freshwater, the existence or absence of fish has been extensively used as a biological indicator of the level of pollution. In acute tests experiments, one of the commonly used measures is the lethal median concentration $\left(\mathrm{LC}_{50}\right)$ that causes mortality in $50 \%$ of the test organisms [25]. Nile tilapia is one of the most common freshwater fish used in toxicological studies [26-28]. Due to its easy handling, culture and maintenance in the laboratory, and because it promptly responds to environmental alterations, this species is also a well-established model for toxicological research $[26,29]$.

Gills are considered as a critical organ to fish because they represent the primary place for gas exchange, ion regulation, and excretion of

${ }^{*}$ Corresponding author: Akram I Alkobaby, Faculty of Agriculture, Department of Animal Production, 'Fish Production' Unit, Cairo University, Egypt, Tel: 00201122339126; E-mail: aialkobaby@agr.cu.edu.eg

Received December 19, 2016; Accepted January 19, 2017; Published January 21, 2017

Citation: Alkobaby Al, Abd El Wahed RK (2017) The Acute Toxicity of Copper to Nile Tilapia (Oreochromis niloticus) Fingerlings and its Effects on Gill and Liver Histology. J Aquac Res Development 8: 465. doi: 10.4172/2155-9546.1000465

Copyright: (c) 2017 Alkobaby Al, et al. This is an open-access article distributed under the terms of the Creative Commons Attribution License, which permits unrestricted use, distribution, and reproduction in any medium, provided the original author and source are credited. 
metabolic waste products. With a wide surface area open to the external milieu, gills are also the first target to waterborne pollutants [30,31]. When present at high concentrations, copper was reported to cause severe histopathological changes in gills of teleost fish [2,32-40]. Gill damage can be linked to impaired physiological function in fish [41]. Lease et al. [42] found gill histopathology is useful as an early-indicator to monitor fish health in the environment. To quantitatively characterize the histopathological changes caused by waterborne toxicants, several studies have used morphometric methods to analyze the thickness of the filamentary epithelium [34].

The liver plays a main role in the metabolism and excretion of xenobiotic compounds with morphological changes occurring in some toxic conditions [43]. It was reported that metals can increase or decrease the activities of hepatic enzyme and can lead to histopathological hepatic alterations, depending on fish species, the metal type and concentration, length of exposure and other factors [44]. The monitorization of histological changes in fish liver is a highly sensitive and accurate way to assess the effects of xenobiotic compounds in field and experimental studies. However, the copper poisoning can cause pathological injury in various tissues such as liver [38,45-47], kidneys [48] and cardiomyocytes structure [49].

Hence, the aim of this study was to investigate the effects of acute toxicity of copper as copper sulfate $\left(\mathrm{CuSO}_{4} \cdot 5 \mathrm{H}_{2} \mathrm{O}\right)$ on histopathological aspects of gills and liver, and to determine the value of $\mathrm{CuSO}_{4}$ lethal concentration $\left(96 \mathrm{~h}-\mathrm{LC}_{50}\right.$ ) for Nile tilapia fingerlings in order to determine specific safety concentrations.

\section{Materials and Methods}

\section{Fish and maintenance}

Healthy Nile tilapia fingerlings, Oreochromis niloticus, weighing $2.97 \pm 0.37 \mathrm{~g}$ with total length of $5.39 \pm 0.26 \mathrm{~cm}$ were collected from the concrete tanks in fish research Unit, Faculty of Agriculture, Cairo University. For acclimation to laboratory conditions, fish were placed into 60-L glass aquaria in the laboratory supplied with continuous aerated well-water for 3 weeks prior to the experiment. During this period supplemental aeration was provided to maintain the dissolved oxygen near saturation. Water temperature $\left(23 \pm 0.1^{\circ} \mathrm{C}\right), \mathrm{pH}(8.2)$ and total alkalinity $\left(195.66 \mathrm{mg} \mathrm{L}^{-1}\right.$ as $\mathrm{CaCO}_{3}$ ) were measured. Fish were fed "ad libitum" twice daily with pelleted $35 \%$ protein commercial tilapia food, and kept with a photoperiod of $12 \mathrm{~h}$ light $-12 \mathrm{~h}$ darkness. Uneaten food was collected after $1 \mathrm{~h}$ and water exchanges were $100 \%$ every $24 \mathrm{~h}$.

\section{Acute toxicity test}

The water used in the toxicity tests was the same as the acclimation period and feeding was stopped 24 hours prior the beginning of $96 \mathrm{~h}-$ $\mathrm{LC}_{50}$ test. After acclimation period, the lethal concentration test of $\mathrm{Cu}$ after $96 \mathrm{~h}\left(96-\mathrm{h} \mathrm{LC}_{50}\right)$ of exposure was conducted in $60-\mathrm{L}$ glass aquaria equipped with airstones to maintain dissolved oxygen levels greater than $75 \%$ saturation. Each aquarium contained 10 fish. Nile tilapia fingerlings were exposed to 0 (control), 5, 10, 15, 20, 25, 30, 35 and $40 \mathrm{mg} \mathrm{L}^{-1}$ copper sulfate $\left(\mathrm{CuSO}_{4} \cdot 5 \mathrm{H}_{2} \mathrm{O}\right)$ (the calculated copper concentration values were $1.25,2.54,3.82,5.09,6.36,7.63,8.91$ and $10.18 \mathrm{mg} \mathrm{Cu} \mathrm{L}^{-1}$, respectively). Three replications per treatment in static renewal-toxicity test were performed to determine $96 \mathrm{~h}-\mathrm{LC}_{50}$. Copper sulfate was purchased from Sigma (Egyptian International Center for Import, Cairo, Egypt), and then stock solution was prepared with distilled water and renewed every $24 \mathrm{~h}$ to maintain water quality.

The amount of copper sulfate to be added in each aquarium was calculated after the volume of each aquarium was accurately determined. No food was provided to the fish during the test. The control group was submitted to the same protocol but without adding copper. All feces and residues were removed daily by suction, and the dead fish were recorded daily and removed from the aquaria. The mortality rate was determined at the end of the 96th hour. During the exposure to different concentrations of copper sulfate, the behavioral changes of the fishes were also recorded. However, Copper $96-\mathrm{h} \mathrm{LC}_{50}$ test was performed as described in the National Exposure Research Laboratory of the U.S. Environmental Protection Agency [50].

\section{Histology}

Three fish were taken randomly from each treatment at the final time point for dissection and histological examinations, then were anesthetized by immersion in clove oil solution $\left(0.05 \mathrm{ml} \mathrm{L}^{-1}\right)$ for $5-10$ min and euthanized by decapitation. Changes in some organs were observed by the naked eye. The second gill arches from both opercular cavities and then liver were harvested from control and exposed fish. Tissue specimens were first fixed in $10 \%$ buffered formalin for $24 \mathrm{~h}$ at $4^{\circ} \mathrm{C}$, and then immediately dehydrated in a graded series of ethanol, immersed in xylol and embedded in paraffin wax. Sagittal sections (5 $\mu \mathrm{m}$ of thickness) were cut and mounted on glass slides. Sections were deparaffinized in xylene, hydratated in ethanol and was stained with hematoxylin-eosin (HE).

Changes induced by treatment in the gill and liver tissues were photographed and analyzed by light microscopy (LEICA DMI300 B microscope and LEICA DFC290 Digital Camera). Gill injuries were quantified by measuring the thickness of secondary lamella epithelium by using an image analysis system (Leica application suite V4, from leica Microsystems). Two primary filaments were selected from the middle of the second gill arch from each fish, and at least the thicknesses of 20 secondary lamellae were measured in each specimen.

\section{Statistical analysis}

Statistical analyses were carried out using statistical SPSS 16 package. A one-way analysis of variance (ANOVA) followed by a Duncan's post hoc test were performed to identify any significant differences between the treatments $(p<0.001)$. All results were given in mean \pm standard error of the mean (S.E.M).

\section{Results}

\section{Fish behavior and anatomy}

No control fish died during the experimental period. Mortality occurred only in the exposed fish and the mortality increased by increasing the concentration of copper sulfate in water. Before death, exposed fish showed unstable swimming with unbalanced movements, exhaustion, suspended in vertical position with the mouth up near the water surface and finally submerged in the bottom of water with no motion. Compared to the control, the treated fish showed pale gills, some damaged gills, flabby intestine, and swelling in liver, gall bladder and spleen.

\section{Acute toxicity}

Estimated mean 96-h LC $_{50}$ value (median lethal concentration) determined in static renewal-toxicity test for Nile tilapia fingerlings was $31.2 \mathrm{mg}$ copper sulfate $\mathrm{L}^{-1}$ (7.94 mg copper $\left.\mathrm{L}^{-1}\right)$.

\section{Gills histology and thickness of secondary lamella epithelium}

The gill morphology of the untreated fish was similar to that of 
Citation: Alkobaby Al, Abd El Wahed RK (2017) The Acute Toxicity of Copper to Nile Tilapia (Oreochromis niloticus) Fingerlings and its Effects on Gill and Liver Histology. J Aquac Res Development 8: 465. doi: 10.4172/2155-9546.1000465

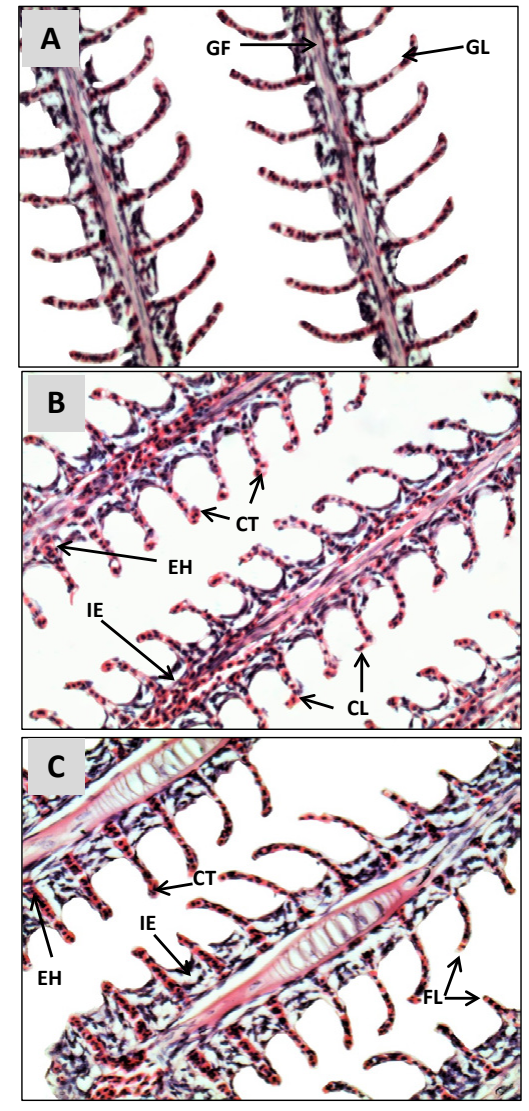

Figure 1: Histopathological changes in gills of O. niloticus. (A) Control treatment showing normal gill filaments (GF) and gill lamella (GL). (B) Gills of fish exposed to $25 \mathrm{mg} \mathrm{L}^{-1}$ copper sulfate, showing epithelial hyperplasia $(\mathrm{EH})$ epithelial interstitial edema (IE), curling in secondary lamella (CL) and clubbed tips of secondary lamella (CT). (C) Gills of fish exposed to $35 \mathrm{mg} \mathrm{L}^{-1}$ copper sulfate, showing hyperplasia of epithelium, edema in the filamentary epithelium with intense lifting in the lamellar epithelium, curling and clubbed tips and finally a complete fusion of several secondary lamellae (FL). Sections (X400) were stained with hematoxylin and eosin.

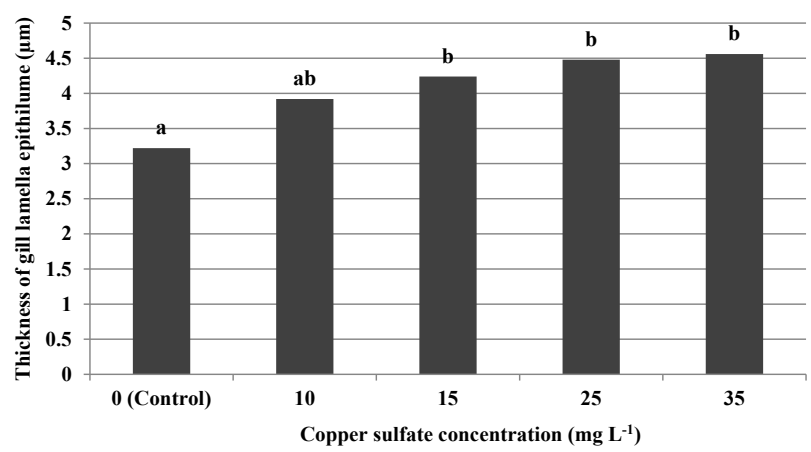

Figure 2: Arithmetic mean thickness of gill lamella epithelium of $O$. niloticus exposed to different concentrations of copper sulfate $\left(\mathrm{mg} \mathrm{L}^{-1}\right)$. Different letters mean statistically significant differences $(P<0.001)$ between copper-exposed and control fish.

other teleost fish species as reported by Wilson and Laurent in 2002 (Figure 1A). Fish which exposed to the different concentrations of $\mathrm{CuSO}_{4}$ showed epithelial lesions. The main alternations observed after the exposure to the copper were epithelial hyperplasia of both primary and secondary lamellae epithelium, the severity of hyperplasia increased with the increase of copper sulfate concentration, leading to the complete fusion of several secondary lamellae at the $35 \mathrm{mg} \mathrm{CuSO}$ $\mathrm{L}^{-1}$ concentration. Lifting of the lamellar epithelium and edema in the filamental epithelium were other lesions observed starting the 15 $\mathrm{mg} \mathrm{L}^{-1} \mathrm{CuSO}_{4}$ exposure concentration. "Curling" and clubbed tips of secondary lamella were also detected (Figures $1 \mathrm{~B}$ and $\mathrm{C}$ ).

As shown in Figure 2, acute exposure to copper increased the arithmetic thickness of gill lamellae epithelium. Statistical analysis showed no significant $(p>0.001)$ differences between thickness of gill lamellae epithelium of the control fish $(3.22 \pm 0.115 \mu \mathrm{m})$ and fish exposed to $10 \mathrm{mg} \mathrm{L}^{-1}$ copper sulfate $(3.92 \pm 0.204 \mu \mathrm{m})$. On the contrary, significant increase $(\mathrm{p}<0.001)$ in epithelial thickness occurred in fish exposed to 15,25 and $35 \mathrm{mg} \mathrm{L}^{-1}$ copper sulfate, where the values of thickness were $4.24 \pm 0.141 \mu \mathrm{m}, 4.48 \pm 0.174 \mu \mathrm{m}$ and $4.56 \pm 0.283$, respectively.

\section{Liver histology}

Our study indicated that the hepatopancreas of control group showed a normal structure without any pathological lesions. The hepatocytes were polygonal cells with a homogenous cytoplasm, and a large central spherical heavily-stained nucleus, also the pancreatic area with its pancreatic acini was obviously normal along the portal vessels within the liver. The hepatic parenchyma of fish exposed to copper sulfate exhibited histological alternations such as cytoplasmic rarefaction and an increase of cytoplasmic vacuolation, the number of hepatocytes nucleus was decreased and nuclear pyknosis was observed (Figures 3A, 3B and 3C). These hepatic alterations were more evident in
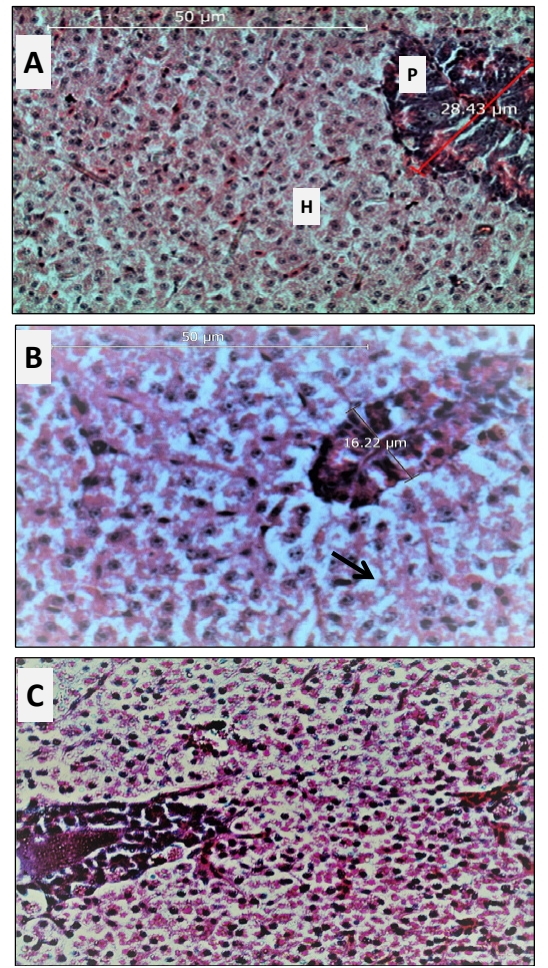

Figure 3: Histopathological changes in liver and pancreas of $O$. niloticus. (A) Control treatment showing normal hepatocytes $(\mathrm{H})$ and pancreatic area $(\mathrm{P})$ that corresponds to the acini of exocrine pancreas. (B) Liver of fish exposed to $25 \mathrm{mg} \mathrm{L}^{-1}$ copper sulfate, showing cytoplasmic vacuolation (arrow), nucleus pyknosis and partial atrophy in the pancreatic tissue. (C) Liver of fish exposed to $35 \mathrm{mg} \mathrm{L}^{-1}$ copper sulfate, showing deterioration of hepatic parenchyma and the acini in pancreatic tissue. Sections (X400) were stained with hematoxylin and eosin. 
fish exposed to $25,30,35$ and $40 \mathrm{mg} \mathrm{L}^{-1}$ copper sulfate concentrations. Furthermore, a partial atrophy in the pancreatic tissue was occurred in fish exposed to $25 \mathrm{mg} \mathrm{L}^{-1}$ copper sulfate, and deterioration of its acini and the acinar arrangement were observed in the fish exposed to higher concentrations of copper sulfate ( 35 and $40 \mathrm{mg} \mathrm{L}^{-1}$ ).

\section{Discussion}

\section{Acute toxicity}

Our toxicity test result supports the observations of Abdel-Tawwab and Mousa [51] who stated that the range of $96-\mathrm{h} \mathrm{LC}_{50}$ for Nile tilapia was 5.03-14.27 mg copper $\mathrm{L}^{-1}$. On the other hand, the 96-h $\mathrm{LC}_{50}$ determined in the present study was higher than other reported values of $1.09,0.853$ and $1.207 \mathrm{mg} \mathrm{Cu} \mathrm{L}^{-1}$ for Nile tilapia [52-54]. This could be due to the differences of fish size and the relatively higher water alkalinity value of our case in comparison to their values. The toxicity of copper sulfate to fish decreases as $\mathrm{pH}$, total alkalinity and total hardness increase, and as copper $(\mathrm{Cu})$ binds to inorganic or organic substrates [17]. Abdel-Tawwab and Mousa [51] found that the pre-exposure to 50-100 $\mathrm{mg} \mathrm{Ca}^{2+} \mathrm{L}^{-1}$ might be effective in reducing the acute toxicity of copper to Nile tilapia fry. Copper sulfate treatments in low-alkalinity waters may be detrimental to the health of blue tilapia [55]. However, Kosai et al. [56] found copper $\mathrm{LC}_{50}-96 \mathrm{~h}$ value for Nile tilapia as 185.8 $\mathrm{mg} \mathrm{L}^{-1}$, which is extremely high compared to our results.

The impact of copper on the aquatic environment is complex and depends on the physicochemical characteristics of water and fish species [57-59]. However, previous researches have been carried out on the 96-h acute toxicity of $\mathrm{Cu}$ and showed many differences between species. These results reported 0.2 to $43.1 \mathrm{mg} \mathrm{Cu} \mathrm{L}^{-1}$ for $O$. aureus [55], 0.24-6.23 mg Cu L $\mathrm{m}^{-1}$ for O. mossambicus [60], $0.092 \mathrm{mg} \mathrm{Cu} \mathrm{L}^{-1}$ for rainbow trout [61], 40.86 for Clarias gariepinus [62] and $0.77 \mathrm{mg} \mathrm{Cu} \mathrm{L}^{-1}$ for Synechogobius hasta [39].

\section{Gills histology and thickness of secondary lamella epithelium}

In this study, histopathological alternations in gills were observed. The detected changes in tilapia gills as gill hyperplasia, Edema, lifting of lamellar epithelia, intense lamellar vasodilation and curling of secondary lamellae were generally accentuated to the lethal effect of copper. This study is in agreement with Mallatt and Fernandes et al. $[30,38]$ who demonstrated that gill hyperplasia and interstitial edema are the more frequent lesions observed in gill epithelium of fish exposed to heavy metals, and with $\mathrm{Al}$ Bairuty et al. and Shaw et al. $[47,63]$ who said that edema may result in osmotic imbalance. The results of this study showed the occurrence of edema independently of copper levels $[2,64]$. The lifting of lamellar epithelium is another histological change observed, probably induced by the incidence of severe edema. In the present study, increasing epithelial lifting and hyperplasia were depending on the increasing of waterborne $\mathrm{Cu}$ concentrations. The last observation is in agreement with other studies [39,65-67]. Edema with lifting of lamellar epithelium and different degrees of hyperplasia are typical defense mechanisms, because separation epithelial of the lamellae increases the pollutant-blood diffusion distance causing gaseous exchange [33]. These gill histological alterations have been observed by several authors in fish submitted to copper $[33,38,40,65,66,68,69]$. At the $25 \mathrm{mg} \mathrm{L}^{-1} \mathrm{CuSO}_{4}$ concentration applied, curling and clubbed tips of secondary lamella were occasionally detected and this finding is in agreement with References [47] and [67], as well as the studies of Gill et al. [70], Skidmore and Tovell [71] who used other types of metals (cadmium on Puntius conchonius and $\mathrm{ZnSO}_{4}$ on Oncorthynchus mykiss, respectively). A complete fusion of several lamellae was recorded at the $35 \mathrm{mg} \mathrm{L}^{-1} \mathrm{CuSO}_{4}$. This could be attributed to the direct effect of heavy metal. The fusion of the secondary lamella was reported by Ostaszewska et al. [67], Al-Bairutya et al. [47]. Accordingly, all these histological changes resulting from the exposure to metals are found to be a compensatory response to keep metal from entering through gill cells $[30,37,66,72]$.

In our study the mean of arithmetic thickness of gill lamellae epithelium was $3.22 \pm 0.115 \mu \mathrm{m}$ in control fish for O. niloticus fingerlings. Those values of thickness of gill lamellae epithelium differ between fish species. O. mossambicus has a mean value of $3.03 \mu \mathrm{m}$ while T. sparrmanni has a mean value of $4.98 \mu \mathrm{m}$ [73]. Studies done by Van Heerden et al. [36] and Lappivaara et al. [74] showed basal thickness of gill lamellae epithelium values for $O$. mykiss of 3.73 and $4.2 \mu \mathrm{m}$, respectively. The significant increase in epithelial thickness happened in this study when fish exposed to $15 \mathrm{mg} \mathrm{L}^{-1}$ copper sulfate $(3.82 \mathrm{mg}$ $\mathrm{L}^{-1} \mathrm{Cu}$ ), while Van Heerden and Tiedt [73] found the increasing in arithmetic thickness of gill epithelium in Oreochromis mossambicus and Tilapia sparrmanii was occurred when exposed to $600 \mu \mathrm{g} \mathrm{L}^{-1}$ and 4.4 $\mathrm{mg} \mathrm{L}^{-1}$ copper, respectively. These variations may be occurred because of the differences of fish species, fish size and the conditions of the experiment. Thickening of epithelium in gills of fish exposed to copper was caused by hypertrophy in cells, beside lamellar telangiectasis. However, morphometric measurements on gills of fish such as the arithmetic thickness of secondary lamella epithelium could be a simple and real indicator of toxic exposure before permanent damage occurs.

\section{Liver histology}

Compared to control the histology showed some alternations in the liver of fish exposed to $15-40 \mathrm{mg} \mathrm{L}^{-1}$ copper sulfate such as cytoplasmic rarefaction and an increase of cytoplasmic vacuolation. The outcome of this study came in agreement with many References $[38,39,44,66,75]$ who demonstrated an increase of cytoplasmic vacuolation. Degenerativenecrotic conditions are often associated with these histological changes [76]. These alternations could be explained by $\mathrm{Cu}$-induced oxidative stress in the tissue of the liver [77]. Our study accentuated that the rate of karyolysis increases with the increase of copper concentration and also observed nuclear pyknosis. Many studies confirm the same alternations $[38,39,66]$. References $[47,66,78]$ suggested that the alterations in size and shape of nucleus may be considered as signs of increasing the metabolic activity but probably of pathological origin.

Furthermore, a partial atrophy in the pancreatic tissue was observed in fish exposed to $25 \mathrm{mg} \mathrm{L}^{-1} \mathrm{CuSO}_{4}$ concentration, and deterioration of its acini and the acinus arrangement were observed in the exposed fish to high concentrations of copper sulfate ( 35 and $40 \mathrm{mg} \mathrm{L}^{-1}$ ) and it could be attributed to the necrotic condition in the tissue. It could be concluded that the liver is a central compartment for the metabolism of $\mathrm{Cu}$ in fish $[79,80]$ and also is the main organ for detoxification and more responsive for damage $[66,75,81]$.

\section{Conclusion}

It could be concluded that although copper sulfate is a good ectoparasite therapeutant, it can be extremely toxic to Nile tilapia, which is relatively tolerant to copper sulfate when compared to other species. The results of this study indicate that exposure to $15 \mathrm{mg} \mathrm{L}^{-1}$ or more of $\mathrm{CuSO}_{4}$ for $96 \mathrm{~h}$ causes significant injuries in gills, liver and panceriatic tissue of Nile tilapia. Furthermore, morphometric measurements on gills of fish such as the arithmetic thickness of secondary lamella epithelium could be a simple and real indicator of toxic exposure before permanent damage occurs. 
Citation: Alkobaby Al, Abd El Wahed RK (2017) The Acute Toxicity of Copper to Nile Tilapia (Oreochromis niloticus) Fingerlings and its Effects on Gill and Liver Histology. J Aquac Res Development 8: 465. doi: 10.4172/2155-9546.1000465

\section{References}

1. Baker JTP (1969) Histological and electron microscopical observations on copper poisoning in the winter flounder (Pseudopleuronectes americanus). J Fish Res Bd Can 26: 2785-2793.

2. Bury NR, Li J, Flik G, Lock RAC, Wendelaar-Bonga SE (1998) Cortisol protects against copper induced necrosis and promotes apoptosis in fish gill chloride cells in vitro. Aquat Toxicol 40: 193-202.

3. WHO (1998) Copper Environmental Health Criteria 200. IPCS-International Programme on Chemical Safety, World Health Organization, Geneva.

4. Wang T, Long X, Cheng Y, Liu Z, Yan S (2014) The potential toxicity of copper nanoparticles and copper sulphate on juvenile Epinephelus coioides. Aquat Toxicol 152: 96-104.

5. Wurts WA, Perschbacher PW (1994) Effects of bicarbonate alkalinity and calcium on the acute toxicity of copper to juvenile channel catfish (Ictalurus punctatus). Aquaculture 125: 73-79.

6. Pelgrom S, Lamers L, Lock R, Balm P, Wendelaar BS (1995) Integrated physiological response of tilapia, Orechromis mossambicus, to sublethal copper exposure. Aquat Toxicol 32: 303-320.

7. Vieira LR, Gravato C, Soares A, Morgado F, Guilhermino L (2009) Acute effects of copper and mercury on the estuarine fish Pomatoschistus microps: linking biomarkers to behaviour. Chemosphere 76: 1416-1427.

8. Grosell M (2012) Homeostasis and toxicology of essential metals, Fish Physiology, Academic Press San Diego.

9. Harris ZL, Githlin JD (1996) Genetic and molecular basis for copper toxicity. Am J Clin Nutr 63: 836S- 841S

10. Grosell M, Wood C M (2002) Copper uptake across rainbow trout gills: Mechanisms of apical entry. J Exp Biol 205: 1179-1188.

11. Lightner DV (1983) Diseases of cultured penaeid shrimp. Handbook of mariculture: crustacean aquaculture. CRC Press Inc., Boca Raton.

12. Boyd CE (1990) Water quality in ponds for aquaculture. Birmingham Publishing Co., Birmingham, Alabama, USA.

13. Mal TK, Adorjan P, Corbett AL (2002) Effect of copper on growth of an aquatic macrophyte, Elodea canadensis. Environ Pollut 120: 307-311.

14. Dores EFG, Freire EMDL (2001) Contaminac,ão do ambiente aqua'tico por pesticidas, estudo de caso: A'guas usadas para consumo humano em Primavera do Leste, Mato Grosso- ana'lise preliminar. Quim Nova 24: 27-36.

15. Bolan NS, Khan MA, Donaldson J, Adriano DC, Mathew C (2003) Distribution and bioavailability of copper in farm effluent. Sci Total Environ 309: 225-236.

16. Oliveira M, Serafim A, Bebianno MJ, Pacheco M, Santos MA (2008) European eel (Anguilla anguilla L.) metallothionein endocrine metabolic and genotoxic responses to copper exposure. Ecotoxicol Environ Saf 70: 20-26.

17. Tucker CS, Robinson EH (1990) Channel Catfish Farming Handbook. Van Nostrand-Reinhold, New York, NY, USA.

18. Schlenk D, Kenneth BD, Griffin BR (1999) Relationship between expression of hepatic metallothionein and sublethal stress in channel catfish following acute exposure to copper sulphate. Aquaculture 177: 367-397.

19. Pavanelli GC, Eiras JC, Takemoto RM (2008) Doenc as de peixes: profilaxia diagno'sticos e tratamentos. Eduem, Maringa.

20. Mitchell MA, Tully TN (2009) Manual of exotic pet practice. Saunders-Elsevier Missouri.

21. Fishery and Aquaculture Country Profiles of Egypt (2010a) Country Profile Fact Sheets. In: FAO Fisheries and Aquaculture Department, Rome.

22. El-Sayed AFM (2013) On-farm feed management practices for Nile tilapia (Oreochromis niloticus) in Egypt. On-farm feeding and feed management in aquaculture. FAO Fisheries and Aquaculture Technical Rome, FAO.

23. Abdel-Tawwab M (2000) Food and feeding habits of Oreochromis niloticus under the effect of inorganic fertilizer with different $\mathrm{N}$ : $\mathrm{P}: \mathrm{K}$ ratios in Abbassa fishponds. Egyptian J of Agric Res 78: 437-448.

24. Abdel-Tawwab M, El-Marakby HI (2004) Length-weight relationship, natura food and feeding selectivity of Nile tilapia; Oreochromis niloticus (L.) in fertilized earthen ponds. The 6 th International Symposium of Tilapia in Aquaculture ISTA 6 , Manila, Philippines.
25. Boateng JO, Nunoo FK, Dankwa HER, Ocran MH (2006) Acute toxic effects of deltamethrin on tilapia, Oreochromis niloticus (Linnaeus, 1758). West Afr J Appl Ecol 9: 1-5.

26. Figueiredo-Fernandes A, Fontaínhas-Fernandes A, Monteiro RAF, ReisHenriques MA, Rocha E (2006) Effects of the fungicide mancozeb in the live structure of Nile tilapia, Oreochromis niloticus - Assessment and quantification of induced cytological changes using qualitative histopathology and the stereological point-sampled intercept method. Bull Environ Contam Toxicol 76 : 249-255.

27. Figueiredo-Fernandes A, Fontaínhas-Fernandes A, Peixoto F, Rocha E, Reis Henriques MA (2006) Effects of gender and temperature on oxidative stress enzymes in Nile tilapia Oreochromis niloticus exposed to paraquat. Pest Biochem Physiol 85: 97-103.

28. Garcia-Santos S, Fontaínhas-Fernandes A, Wilson JM (2006) Cadmium tolerance in the Nile tilapia (Oreochromis niloticus) following acute exposure: Assessment of some iono-regulatory parameters. Environ Toxicol 21: 33-46.

29. Almeida JA, Diniz YS, Marques SF, Faine LA, Ribas BO, et al. (2002) The use of the oxidative stress responses as biomarkers in Nile tilapia (Oreochromis niloticus) exposed to in vivo cadmium contamination. Environ Int 27: 673-679.

30. Mallatt J (1985) Fish gill structural changes induced by toxicants and other irritants: A statistical review. Can J Fish Aquat Sci 42: 630-648.

31. Perry SF, Laurent $P$ (1993) Environmental effects on fish gill structure and function. Fish Ecophysiology. Chapman \& Hall, London, UK.

32. Olsson PE, Kling P, Hogstrand C (1998) Mechanisms of heavy metal accumulation and toxicity in fish. Metal Metabolism in Aquatic Environments. Chapman \& Hall, London, UK.

33. Arellano JM, Storch V, Sarasquete C (1999) Histological changes and coppe accumulation in liver and gills of the Senegales sole, Solea senegalensis Ecotoxicol Environ Saf 44: 62-72.

34. Cerqueira CC, Fernandes MN (2002) Gill tissue recovery after copper exposure and blood parameter responses in the tropical fish Prochilodus scrofa. Ecotoxicol Environ Saf 52: 83-91.

35. Monteiro SM, Rocha E, Mancera JM, Fontanhas-Fernandes A, Sousa M (2009) A stereological study of copper toxicity in gills of Oreochromis niloticus. Ecotoxicol and Environ Saf 72: 213-223.

36. Van Heerden D, Vosloo A, Nikinmaa M (2004) Effects of short-term coppe exposure on gill structure, metallothionein and Hypoxia Inducible Factor-1a (HIF-1a) levels in Rainbow trout (Oncorhynchus mykiss). Aquat Toxicol 69: 271- 280.

37. Abdel-Tawwab M, Mousa MAA, Ahmad MH, Sakr SFM (2007) The use of calcium pre-exposure as a protective agent against environmental copper toxicity for juvenile Nile tilapia, Oreochromis niloticus (L.). Aquaculture 264 236-246.

38. Figueiredo-Fernandes A, Ferreira-Cardoso JV, Garcia-Santos S, Monteiro SM Carrola J, et al. (2007) Histopathological changes in liver and gill epithelium of Nile tilapia, Oreochromis niloticus, exposed to waterborne copper. Pesquisa Veterinária Brasileira 27: 103-109.

39. Liu XJ, Luo Z, Xiong BX, Liu X, Zhao YH, et al. (2010) Effect of waterborne copper exposure on growth, hepatic enzymatic activities and histology in Synechogobius hasta. Ecotoxicol and Environ Saf 73: 1286-1291.

40. Jooyandeh F, Sadeghpour A, Khara H, Pajand Z (2016) Histopathological and bacterial study of skin and gill of grass carp, Ceteopharyngodon idella, (Valenciennes 1844) exposed to copper sulfate and potassium permanganate. J Parasite Dis 40: 1009-1013.

41. Woodward DF, Riley RG, Smith CE (1983) Accumulation, sublethal effects, and safe concentration of a refined oil as evaluated with cutthroat trout. Arch Environ Contam Toxicol 12: 455-464.

42. Lease HM, Hansen JA, Bergman HL, Meyer JS (2003) Structural changes in gills of Lost River suckers exposed to elevated $\mathrm{pH}$ and ammonia concentrations. Comp Biochem Physiol C, Comp Pharmacol Toxicol 134: 491-500.

43. Rocha E, Monteiro RAF (1999) Histology and cytology of fish liver: A review. Ichthyology: Recent research advances. Science Publishers, Enfield, New Hampshire.

44. Paris-Palacios S, Biagianti-Risbourg S, Vernet G (2000) Biochemical and (ultra) structural hepatic perturbation of Brachydanio rerio (Teleostei, Cyprinidae) 
Citation: Alkobaby Al, Abd El Wahed RK (2017) The Acute Toxicity of Copper to Nile Tilapia (Oreochromis niloticus) Fingerlings and its Effects on Gill and Liver Histology. J Aquac Res Development 8: 465. doi: 10.4172/2155-9546.1000465

exposed to two sublethal concentrations of copper sulphate. Aquat Toxicol 50 109-124

45. Nawaz M, Manzl C, Krumschnabel G (2005) In vitro toxicity of copper cadmium, and chromium to isolated hepatocytes from carp, Cyprinus carpio L. Bull Environ Contam Toxicol 75: 652-661.

46. Varanka Z, Rojik I, Varanka I, Nemcsok J, Abraham M (2001) Biochemical and morphological changes in carp (Cyprinus carpio L.) liver following exposure to copper sulfate and tannic acid. Comp Biochem Physiol 128C: 467-478.

47. Al-Bairuty GA, Shaw BJ, Handy RD, Henry TB (2013) Histopathological effects of waterborne copper nanoparticles and copper sulphate on the organs of rainbow trout (Oncorhynchus mykiss). Aquat Toxicol 126: 104-115

48. Jiraungkoorskul W, Sahaphong S, Kangwanrangasan N (2007) Toxicity of copper in butterfish (Poronotus triacanthus): Tissues accumulation and ultrastructural changes. Environ Toxicol 22: 92-100.

49. Waldemarin KCA, Alves RN, Beletti ME, Rantin FT, Kalinin AL (2012) Copper sulfate affects Nile tilapia (Oreochromis niloticus) cardiomyocytes structure and contractile function 21: 783-794.

50. National Exposure Research Laboratory (NERL) (2002) Methods for measuring the acute toxicity of effluents and receiving waters to freshwater and marine organisms. U.S. Environmental Protection Agency, Pennsylvania, Washington, DC.

51. Abdel-Tawwab M, Mousa MAA (2005) Effect of calcium pre exposure on acute copper toxicity to juvenile Nile tilapia, Oreochromis niloticus (L.) Zagazig Vet J 33: 80-87.

52. Abdulali TMS, Ahmad AK (2013) In vivo acute toxicity tests of some heavy metals to tilapia fish (Oreochromis niloticus). J of Biol Sci 13: 365-371.

53. Soeung L (2015) Ecotoxicology of copper on local freshwater organisms in Mekong River Cambodia. Inter J of Environ and Rural Develop 6-1.

54. Monteiro SM, Oliveira E, Fernandes AF, Sousa M (2012) Effects of sublethal and lethal copper concentrations on the gill epithelium ultrastructure of Nile Tilapia, Oreochromis niloticus. Zoological Studies 51: 977-987.

55. Straus DL (2003) The acute toxicity of copper to blue tilapia in dilutions of settled pond water. Aquaculture 219: 233-240.

56. Kosai P, Jiraungkoorskul W, Thammasunthorn T, Jiraungkoorskul K (2009) Reduction of copper-induced histopathological alterations by calcium exposure in Nile tilapia (Oreochromis niloticus). Toxicol Mech Meth 19: 461-467.

57. Laurén DJ, Mcdonald DG (1986) Influence of water hardness, pH, and alkalinity on the mechanisms of copper toxicity in juvenile rainbow trout; Salmo gairdneri. Can J Fish Aquat Sci 43: 1488-1496.

58. Svobodova Z, Lloyd R, Machova J, Vykusova B (1993) Water Quality and Fish Health. FAO, Rome.

59. Takasusuki J, Araujo MRR, Fernandes MN (2004) Effect of water pH on copper toxicity in the neotropical fish, Prochilodus scrofa (Prochilodondidae). Bulletin of Environ Contam and Toxicol 72: 1075-1082.

60. Chen WY, Lin CJ, Ju ZR, Tsai JW, Liao CM (2012) Assessing the effects of pulsed waterborne copper toxicity on life-stage tilapia populations. Sci of the Total Environ 417-418: 129-137.

61. Chowdhury MJ, Girgis M, Wood CM (2016) Revisiting the mechanisms of copper toxicity to rainbow trout: Time course, influence of calcium, unidirectional $\mathrm{Na}+$ fluxes, and branchialNa+, $\mathrm{K}+\mathrm{ATP}$ ase and V-type H+ATPase activities. Aquat Toxicol 177: 51-62.

62. Wani AA, Sikdar-Bar M, Khan HA (2013) Acute toxicity of copper sulphate to African catfish, (Clarias gariepinus). GERF Bulletin of Biosciences 4: 14-18.

63. Shaw BJ, Al-Bairuty GA, Handy RD (2012) Effects of waterborne copper nanoparticles and copper sulphate on rainbow trout, (Oncorhynchus mykiss): physiology and accumulation. Aquat Toxicol 116-117: 90-101.
64. Sola F, Isaia J, Masoni A (1995) Effects of copper on gill structure and transport function in the rainbow trout, Oncorhynchus mykiss. J Appl Toxicol 15: 391-398.

65. Karan V, Vitorovic S, Tutundzic V, Poleksic V (1998) Functional enzymes activity and gill histology of carp after copper sulfate exposure and recovery. Ecotoxicol Environ Saf 40: 49-55

66. Chen QL, Luo Z, Zheng JL, Li XD, Liu CX, et al. (2012) Protective effects of calcium on copper toxicity in Pelteobagrus fulvidraco: Copper accumulation, enzymatic activities, histology. Ecotoxicol and Environ Saf 76: 126-134.

67. Ostaszewska T, Chojnacki M, Kamaszewski M, Sawosz-Chwalibóg E (2016) Histopathological effects of silver and copper nanoparticles on the epidermis, gills, and liver of Siberian sturgeon. Environ Sci Pollut Res 23: 1621-1633.

68. De Boeck G, Vlaeminck A, Balm PH, Lock RA, De Wachter B, et al. (2001) Morphological and metabolic changes in common carp, Cyprinus carpio, during short-term copper exposure: Interactions between $\mathrm{Cu}^{2+}$ and plasma cortisol elevation. Environ Toxicol Chem 20: 374-381.

69. Chen JC, Lin CH (2001) Toxicity of copper sulfate for survival, growth, molting and feeding of juveniles of the tiger shrimp, Penaeus monodon. Aquaculture 192: 55-65.

70. Gill TS, Pant JC, Tewari H (1988) Branchial pathogenesis in a freshwater fish Puntius conchonius Ham., chronically exposed to sub- lethal concentrations of cadmium. Ecotoxicol Environ Saf 15: 153-161.

71. Skidmore JF, Tovell PWA (1972) Toxic effects of zinc sulphate on the gills of rainbow trout. Water Res 6: 217-230.

72. Dange Z, Balm PH, Falik G, Wendelaar-Bonga SE, Lock RA (2000) Cortiso increases $\mathrm{Na}+/ \mathrm{K}+-\mathrm{ATP}$ ase density in plasma membranes of gill chloride cells in the freshwater tilapia; Oreochromis mossambicus. J of Exp Biol 203 2349-2355.

73. Van Heerden DLR, Tiedt AV (2004) Gill damage in Oreochromis mossambicus and Tilapia Sparrmanii after short-term copper exposure. International Congress Series 1275: 195-200.

74. Lappivaara J, Nikinmaa M, Tuurala H (1995) Arterial oxygen tension and the structure of the secondary lamellae of the gills in rainbow trout (Oncorhynchus mykiss) after acute exposure to zinc and during recovery. Aquat Toxicol 32: 321-331.

75. Velmurugan B, Selvanayagam M, Cengiz El, Unlu E (2007) Histopathology of lambda-cyhalothrin on tissues (gill, kidney, liver and intestine) of Cirrhinus mrigala. Environ Toxicol Pharmacol 24: 286-291.

76. Myers MS, Rhodes LD, McCain BB (1987) Pathologic anatomy and patterns of occurrence of hepatic neoplasms, putative preneoplastic lesions, and other iodiopathic hepatic conditions in English sole (Parophrys vetulus) from Puget Sound, Washington. J Natl Cancer Inst 78: 333-363.

77. Hoyle I, Shaw BJ, Handy RD (2007) Dietary copper exposure in the African walking catfish, Clarias gariepinus: transient osmoregulatory disturbances and oxidative stress. Aquat Toxicol 83: 62-72.

78. Braunbeck T, Storch V, Bresch H (1990) Species-specific reaction of liver ultrastructure in zebra fish (Brachydanio rerio) and trout (Salmo gairdneri) after prolonged exposure to 4-chloroaniline. Arch Environ Contam Toxicol 19: 405-418.

79. Grosell M, Boetius I, Hansen HJM, Rosenkilde P (1996) Influence of pre exposure to sublethal levels of copper on 64Cu uptake and distribution among tissues of the european eel (Anguilla anguilla). Comparative Biochemistry and Physiology, Part C: Pharmacol Toxicol \& Endocrinol 114: 229-235.

80. Handy RD, Sims DW, Giles A, Campbell HA, Musonda MM (1999) Metabolic trade-off between locomotion and detoxification for maintenance of blood chemistry and growth parameters by rainbow trout (Oncorhynchus mykiss) during chronic dietary exposure to copper. Aquat Toxicol 47: 23-41.

81. Bernet D, Schmidt H, Meier W, Brkhardt-Holm P, Wahli T (1999) Histopathology in fish: Proposal for a protocol to assess aquatic pollution. J Fish Dis 22: 25-34 